Historia Slavorum Occidentis

2021, nr 3 (30)

ISSN 2084-1213

DOI: $10.15804 /$ hso210305

Zbyszko Górczak (PoznaŃ)

ORCID: 0000-0002-9258-145X

\title{
Zagadnienie organizacji państwa i społeczeństwa polskiego w epoce piastowskiej w dorobku naukowym Aleksandra Gieysztora oraz Gerarda Labudy
}

Słowa kluczowe: państwo, społeczeństwo, militaryzacja, miasta Keywords: state, society, militarisation, towns

\begin{abstract}
The main theses of the authors concerned the mutual relation between social changes and the formation of state organisation, the militarisation of the Early Piast State (G. Labuda) and the question of the native, pre-foundation beginnings of urban life in Poland. In their research, A. Gieysztor and G. Labuda often used the methods of retrogression and comparison; in addition, G. Labuda appreciated the importance of archaeological findings.
\end{abstract}

Aleksander Gieysztor (1916-1999) oraz Gerard Labuda (1916-2010) to dwie wielkie postacie mediewistyki polskiej. Ich praca naukowa rozpoczęła się w latach międzywojennych, by osiągnąć apogeum w niełatwym okresie PRL-u, trwała też nadal po wydarzeniach 1989 r. Obydwaj zajmowali się pozornie odległymi w czasie zagadnieniami z dziejów średniowiecza, ich prace oraz wyniki badań znajdowały jednak żywy oddźwięk nie tylko w środowisku zawodowych historyków czy miłośników przeszłości.

Wspomniani uczeni mają w swoim dorobku imponującą liczbę monografii, rozpraw, artykułów, recenzji dotyczących całego wachlarza zagadnień związanych z dziejami politycznymi, społecznymi, gospodarczymi czy kulturą wczesnośre- 
dniowiecznej Polski oraz krajów ościennych. W ich badaniach sporo miejsca zajęła tematyka organizacji państwa piastowskiego oraz zachodzące w dobie monarchii piastowskiej przemiany społeczne. Zagadnienia te, o fundamentalnym znaczeniu dla poznania i zrozumienia wczesnych dziejów państwa oraz formującego się narodu, przyciągały uwagę wielu najwybitniejszych przedstawicieli polskiej nauki historycznej właściwie od samego początku jej istnienia jako nowoczesnej dyscypliny naukowej. Uwarunkowania polityczne dwudziestowiecznych dziejów Polski, zarówno w kwestiach wewnętrznych, jak i międzypaństwowych, przyczyniły się przy tym w różnych okresach do intensyfikacji zainteresowania powyższą tematyką, ale też wywierały pewien wpływ na interpretację wyników badań oraz sposób ich prezentacji. Wpływ ten przejawiał się np. w ożywionych polemikach z historiografią niemiecką odnośnie do różnych aspektów przemian społecznych, gospodarczych i politycznych w średniowiecznej Polsce, w których to dyskusjach istotny udział brali obydwaj uczeni. Inną kwestią stał się nacisk ideologii oraz metodologii marksistowskiej, narzucanej przez władze w polskich naukach humanistycznych, w tym i historycznej, zwłaszcza w latach pięćdziesiątych. Zarówno A. Gieysztor, jak i G. Labuda zajmowali też zdecydowane stanowisko metodologiczne dotyczące możliwości poznawczych współczesnego historyka w odniesieniu do bardzo słabo oświetlonych źródłowo zagadnień organizacji państwa i społeczeństwa w dobie wczesnopiastowskiej. Uważali, że problematykę tę można i należy badać także w oparciu o źródła pośrednie, retrogresję czy metody porównawcze, a praktyczny wyraz temu przekonaniu dali we własnej pracy naukowej i publikowanych rozprawach.

Przyznać przy tym trzeba, że problematyka organizacji i ustroju państwa piastowskiego, a także zachodzących w nim przemian społecznych i gospodarczych więcej miejsca zajmowała zawsze w pracy naukowej G. Labudy, dla którego zagadnienia te stanowiły jedno z centralnych pól badawczych, podczas gdy uwagę A. Gieysztora $\mathrm{w}$ coraz większym stopniu przyciągały kwestie budzenia się i rozwoju świadomości narodowej oraz kultury średniowiecznej Polski, przedstawiane często na szerokim tle ogólnoeuropejskim.

Swego rodzaju kompendium poglądów A. Gieysztora na zagadnienie powstania oraz wczesnej organizacji państwa piastowskiego można znaleźć w przygotowanych przezeń rozdziałach zbiorowej monografii Historia Polski, opublikowanej w 1957 r. pod redakcją H. Łowmiańskiego ${ }^{1}$. Jest to publikacja dość szczególna i trudno ją jednoznacznie ocenić. Powstała na granicy epok. Wydano ją już po przełomie 1956 r.,

1 Historia Polski, t. 1, cz. 1, red. H. Łowmiański, Warszawa 1957. 
w latach odwilży gomułkowskiej. Prace nad monografią trwały jednak kilka lat i podstawowe założenia, a zapewne i treść poszczególnych rozdziałów autorzy oraz redaktorzy musieli przygotować już wcześniej. Stąd widoczne są w tej publikacji wpływy założeń marksistowskich, lansowane ze szczególną siłą właśnie w latach poprzedzających zmiany 1956 r. Elementy te daje się zauważyć także w opiniach A. Gieysztora, aczkolwiek z różną siłą. W późniejszych latach uwagę uczonego przyciągały $\mathrm{w}$ większym stopniu inne, wspomniane wyżej tematy badawcze; do problematyki początków i organizacji państwa piastowskiego oraz panujących w nim stosunków społecznych wracał nieczęsto. Dlatego też kolejną zauważalną cechą prezentowanych przez A. Gieysztora poglądów stał się brak odniesienia do nowszych wyników badawczych, przedstawionych zwłaszcza przez archeologię. Trzeba zresztą zaznaczyć, że w swojej pracy historyka obydwaj uczeni przykładali największą wagę do świadectwa przekazów pisanych, źródła o innym charakterze, w tym archeologiczne, traktując z pewną ostrożnością.

Inaczej niż A. Gieysztor, G. Labuda bardzo często powracał w pracy badawczej do różnych aspektów dziejów państwa piastowskiego. Swoje poglądy zawarł w wielu monografiach i opracowaniach szczegółowych, jednak - co ciekawe - za ich podsumowanie, przedstawione także szerszemu kręgowi miłośników historii, można uznać nie taką czy inną publikację o charakterze ściśle naukowym, lecz dwa kolejne tomy z serii „Dzieje narodu i państwa polskiego”, przygotowane na przełomie lat osiemdziesiątych i dziewięćdziesiątych XX w. ${ }^{2}$ Pomimo popularnonaukowego założenia tej serii wspomniane tomy prezentują nadzwyczaj wysoki poziom wiedzy historycznej i opierają się na własnych badaniach Autora, zawierając także elementy polemiczne, odnoszące się do innych koncepcji wyrażanych w literaturze przedmiotu. G. Labuda, pomimo przejawianej niekiedy ostrożności w stosunku do osiągnięć archeologii, wykorzystał we wspomnianych pracach także nowsze ustalenia badawcze tej dyscypliny. Ostatnią okazją do wypowiedzenia się w sposób kompleksowy na temat różnych kwestii związanych z organizacją państwa i społeczeństwa piastowskiego stała się opublikowana w 2002 r. monografia poświęcona Mieszkowi $I^{3}$. Publikacja ta również ma w założeniu charakter popularnonaukowy, wykazuje jednak cechy opracowania ściśle naukowego. Niestety, okazała się dużo mniej udana od wydanych wcześniej tomów z serii „Dzieje narodu i państwa polskiego”. Poglądy

2 G. Labuda, Pierwsze państwo polskie, Warszawa 1989; tenże, Korona i infuta. Od monarchii do poliarchii, Warszawa 1996.

3 Tenże, Mieszko I, Wrocław 2002. 
Autora zostały wyłożone w sposób nieuporządkowany i nieco chaotyczny. Wolno w tym widzieć skutek nałożenia się pewnych niedostatków pracy redakcyjnej wydawnictwa, specyficznej metody przygotowywania własnych publikacji przez uczonego (wprowadzania do ostatniej chwili istotnych poprawek), a także pogarszającego się stanu wzroku G. Labudy, co uniemożliwiło osobistą kontrolę i korektę tekstu. Najlepszym wykładem poglądów uczonego na interesujące mnie kwestie pozostają więc wspomniane wyżej opracowania z lat osiemdziesiątych i dziewięćdziesiątych.

W podstawowych kwestiach przemian społecznych i politycznych prowadzących do powstania państwowości piastowskiej obydwaj Autorzy prezentowali sporą zgodność poglądów. Akcentowali dużą rolę opola w życiu społeczności plemiennej, przypisując tej przedpaństwowej organizacji o charakterze terytorialnym szeroki i w miarę ustabilizowany zakres kompetencji sądowniczych oraz skarbowych. Uprawnienia te miała następnie przejąć władza książęca. Uczeni opierali się przy tym głównie na metodzie retrogresji, wnioskując na podstawie dużo późniejszych źródeł, pochodzących już z doby państwa piastowskiego. Metoda ta, stosowana zresztą także przez innych badaczy, stała się później przedmiotem kontrowersji i polemik w nowszej historiografii. Sam mechanizm wytworzenia się władzy książęcej, a tym samym organizacji państwowej, obydwaj uczeni także przedstawiali w miarę zgodnie, w ślad za klasycznymi dla tej kwestii hipotezami Kazimierza Tymienieckiego, akcentującymi rolę wojny, obieranego przez wiec wodza wojennego (wojewody) - dążącego do utrwalenia i umocnienia swojej czasowej początkowo pozycji - oraz drużyny jako głównego narzędzia realizacji tych ambicji i oparcia dla rodzącej się władzy monarszej. Pewne rozbieżności dotyczyły natomiast czasu zajścia omawianych procesów. A. Gieysztor, idąc za poglądami powszechnie ugruntowanymi w czasie powstawania jego rozprawy, sytuował początki państwowości polańskiej w głębi IX w., podczas gdy G. Labuda mógł już skorzystać z nowszych ustaleń archeologii dotyczących datowania najstarszych grodów piastowskich i dopiero drugą ćwierć X w. uznał za moment narodzin państwa Piastów.

Za prawdziwy „kościec” państwa i podstawę jego struktury administracyjnej obydwaj uczeni uznali grody książęce. Proces ich wznoszenia, przy uprzednim niszczeniu starszych gródków plemiennych, wyznaczał postępy w organizacyjnym i terytorialnym umacnianiu się monarchii. Grody pełniły funkcje nie tylko militarne, lecz także administracyjne, będąc siedzibą lokalnych władz wojskowych, sądowo-policyjnych oraz gospodarczych - odpowiedzialnych za zbieranie danin i organizowanie posług miejscowej ludności. O ile dwa pierwsze aspekty administracyjnej 
roli grodów nie budziły nigdy większych wątpliwości w literaturze, o tyle ostatni - zarząd gospodarczy - stał się przedmiotem dyskusji. Obydwaj Autorzy opowiedzieli się w tym wypadku za tzw. „teorią grodową”, negatywnie podchodząc do poglądów zwolenników tzw. „teorii dworskiej” (Roman Grodecki, Karol Buczek). Ci ostatni zadania gospodarcze wyłączali spod kompetencji administracji grodowej (od przełomu XII i XIII w. można ją bez obawy anachronizmu terminologicznego nazywać kasztelańską), a w roli poborców danin i świadczeń ludności widzieli osobnych włodarzy, rezydujących w specjalnie wznoszonych dworach książęcych. Badając zagadnienie zadań administracyjnych organizacji grodowej, A. Gieysztor i G. Labuda także w tym wypadku stosowali metodę retrogresji, wykorzystując źródła dokumentowe wytworzone w późniejszych stuleciach, oraz odwoływali się do porównań z krajami ościennymi.

Specyficzną cechą ustaleń badawczych G. Labudy, mniej może akcentowaną przez A. Gieysztora, stał się nacisk na kwestię militaryzacji państwa pierwszych Piastów. G. Labuda wielokrotnie podkreślał ten właśnie aspekt funkcjonowania najstarszej monarchii piastowskiej. Rozbudowana siła zbrojna księcia, której rdzeń i najwartościowszą część stanowiła drużyna, tworzyła podporę jego władzy, a utrzymanie wojska stawało się wręcz głównym celem działania innych agend państwa. Tu właśnie G. Labuda upatrywał przyczyn agresywnej polityki zagranicznej Bolesława Chrobrego (drużynie należało zapewnić zajęcie oraz okazję zdobycia łupów), a także rosnących ciężarów nakładanych na ludność wieśniaczą. W ostatecznym rachunku obydwa te czynniki miały doprowadzić do kryzysu i upadku państwa pierwszych Piastów ${ }^{4}$. Zauważyć wypada, że poglądy te G. Labuda wyrażał bardzo konsekwentnie, nie bacząc na ich swego rodzaju niewygodny wydźwięk, odnoszący się do różnych pozanaukowych dyskusji o zabarwieniu politycznym i propagandowym.

O ile widać ogólną zgodność poglądów obydwu uczonych odnośnie do podstaw organizacyjnych i administracyjnych państwa piastowskiego, o tyle daje się zauważyć pewną różnicę zdań w kwestii mechanizmów zachodzących przemian społecznych, zmierzających w ogólnym rozrachunku ku pogłębiającemu się rozwarstwieniu i feudalizacji. Zarówno A. Gieysztor, jak i G. Labuda odrzucali przestarzałe, ale podnoszone jeszcze we wczesnych latach ich pracy naukowej poglądy o teorii najazdu jako wytłumaczenia i początków państwa, i zróżnicowania społecznego ludności. $\mathrm{W}$ toku dalszej analizy tego zagadnienia zdania obydwu uczonych poszły się jednak

4 Tenże, Przeobrażenia $w$ organizacji polskich sił zbrojnych $w$ XI w., [w:] Pax et bellum, red. K. Olejnik, Poznań 1993, s. 87-110. 
w różnych kierunkach. A. Gieysztor zdawał się nawiązywać do starszych hipotez historiografii, widzących początki wielkiej własności ziemskiej, uzależnienia ludności wieśniaczej oraz procesu feudalizacji już w okresie przedpaństwowym. To arystokracja plemienna miała gromadzić dobra ziemskie oraz uzależniać od siebie rzesze pospolitych wieśniaków. Powstająca organizacja państwowa miała służyć utrzymaniu i utrwaleniu tych przemian oraz pozycji arystokratycznej elity. W tym miejscu należy przypomnieć, że poglądy te Autor wyraził we wspomnianej pracy powstałej w połowie lat pięćdziesiątych XX w. Nie stanowiły one nowości i przedstawiano je już w starszej literaturze, niemniej odpowiadały doskonale ogólnym postulatom teorii marksistowskiej, która zakładała, że zmiany w tzw. „bazie” (czyli przemiany stosunków gospodarczych i społecznych - zwłaszcza dotyczących własności środków produkcji, w tym wypadku przede wszystkim ziemi uprawnej) powinny poprzedzać zmiany w tzw. „nadbudowie” (czyli przemiany polityczne i następnie ideologiczne). W takim ujęciu państwo piastowskie miało powstać jako swego rodzaju emanacja rosnącej w siłę arystokracji plemiennej i służyło realizacji jej interesów. Konkretne mechanizmy tego procesu (rola wojny, wodza i drużyny) stawały się już kwestią drugorzędną. Trudno obecnie stwierdzić, czy A. Gieysztor istotnie przyjął w dobrej wierze postulaty teorii marksistowskiej (które dla sporego grona ówczesnych historyków wydawały się atrakcyjne i nowatorskie pod względem poznawczym), czy też przedstawienie takich poglądów stanowiło swego rodzaju konieczną „daninę" względem władz i panującej oficjalnie ideologii. Przyznać trzeba, że uczony nie zagłębiał się zbytnio $\mathrm{w}$ ten akurat aspekt swoich wywodów i zachował daleko posuniętą ostrożność przy formułowaniu wniosków. Stwierdzil, że w epoce plemiennej zaledwie rozpoczęły się procesy rozwarstwienia społecznego, feudalizacji oraz gromadzenia dóbr ziemskich. Przykładowo starszyzna posiadała jakoby majątki nieprzekraczające wielkością „kilku wsi”. Wszystkie te opinie, dotyczące formowania się wielkiej własności ziemskiej oraz ogólnie procesów feudalizacji społeczeństwa w epoce przedpaństwowej, nie zostały zresztą poparte analizą materiału źródłowego i sprawiają wrażenie raczej deklaratywne.

Inaczej postrzegał ten kluczowy dla ewolucji społeczeństwa problem G. Labuda. Jego zdaniem decydującą rolę odegrało tu właśnie powstanie organizacji państwowej. Wytworzyła się ona nie za sprawą dotychczasowej starszyzny czy też arystokracji plemiennej, lecz niejako obok niej, a nawet w opozycji do uprzednich elit. Decydującą rolę odegrał przywódca wojenny (wojewoda, książę) oraz formująca się

5 Historia Polski, t. 1, cz. 1, s. 144. 
wokół niego drużyna. Członkowie tej grupy, która miała stać się nową elitą, nie musieli wcale wywodzić się z grona arystokracji plemiennej, a bardziej prawdopodobne wydaje się nawet to, że stanowili raczej specyficzną zbieraninę różnego rodzaju niespokojnych duchów, awanturników czy wręcz przybyszów z obcych stron. W każdym razie byli to ludzie, którzy w tradycyjnych strukturach plemiennych odgrywali rolę niewielką lub żadną. Osiągnięty obecnie status zawdzięczali wodzowi (księciu) i stanowili też główną podporę jego władzy. Tradycyjna arystokracja plemienna nie tylko nie skorzystała jako grupa na tych przemianach, ale prawdopodobnie straciła zajmowaną pozycję albo uległa wręcz fizycznej likwidacji, co potwierdzają ślady źródłowe. To za pośrednictwem tworzącego się państwowego aparatu administracyjnego nowa elita, skupiona wokół dworu książęcego oraz drużyny, zdobyła władzę nad ludnością pospolitą oraz możliwość jej eksploatacji. Korzyści osobiste osiągała przez piastowanie z ramienia księcia urzędów i funkcji państwowych oraz udział w ściąganych w imieniu władcy daninach. Dopiero z czasem tę wygodną i początkowo jedynie możliwą formę uzależnienia zaczęła zastępować eksploatacja indywidualna, polegająca na rozdawnictwie dóbr ziemskich przez księcia. Dokonało się to zresztą w warunkach przymusowych - kryzysu państwa i rozpadu jego struktur administracyjnych w połowie XI w. Władca, nie będąc już w stanie utrzymywać siły zbrojnej $\mathrm{w}$ dotychczasowy sposób, nadawał posiadłości drużynnikom oraz innym ludziom w swej służbie, zezwalając na bezpośrednie, indywidualne pobieranie świadczeń. Politykę tę miał zapoczątkować Kazimierz Odnowiciel, a kontynuowali ją jego następcy. Początki wielkiej, feudalnej własności ziemskiej oraz osobistego uzależnienia wieśniaków nie wyprzedzały więc procesu państwotwórczego ani też nie stanowiły jego siły sprawczej. Przeciwnie, to dopiero władza monarsza przyczyniła się walnie do feudalizacji społeczeństwa ${ }^{6}$.

W tym punkcie uczony zajął też stanowisko w innej, mocno dyskutowanej kwestii związanej z organizacją oraz przemianami społeczno-gospodarczymi zachodzącymi w monarchii piastowskiej - istoty regale ziemnego oraz przedmiotu nadań książęcych dla możnych, Kościoła i rycerstwa. Zasadniczo instytucja regale ziemnego oznaczała, że całość ziemi w państwie należała do osoby monarchy, prawem zdobywcy lub jako dziedzica uprzednich struktur plemiennych i opolnych. Nie budził większych wątpliwości taki status lasów i innych obszarów nieeksploatowanych gospodarczo w bezpośredni sposób. Dyskusja dotyczyła natomiast statusu gruntów uprawnych, na których gospodarowali wieśniacy. Część autorów, np. Henryk Ło-

6 G. Labuda, Przeobrażenia w organizacji, s. 90 i n. 
wmiański ${ }^{7}$, uważała, że w powstającym państwie książę stał się właścicielem i tych ziem. Zezwalał oczywiście gospodarować na nich kmieciom, ale zobowiązani oni byli z tego tytułu do określonych danin i posług, traktowanych jako świadczenia prywatno-prawne. W przyszłości, monarcha jako właściciel ziem uprawnych przystąpił do nadawania ich możnym, Kościołowi i rycerstwu, przy czym darowizny te dotyczyć miały zarówno ziemi, jak i zamieszkujących na niej ludzi. Znalazło to wyraz w sformułowaniach trzynastowiecznych aktów nadań.

G. Labuda nie zgodził się z tymi poglądami i poparł tutaj stanowisko przeciwne, reprezentowane m.in. przez Karola Modzelewskiego ${ }^{8}$. Zakładało ono, że regale ziemne monarchy nie obejmowało w okresie wczesnopiastowskim ziemi uprawianej przez ludność wieśniaczą. Stanowiła ona nadal własność samych chłopów, ograniczaną w coraz słabszy sposób przez dawne zwyczaje opolne. Książę stawał się wręcz w nowych warunkach powstającego państwa i upadku starych struktur gwarantem posiadania tych gruntów przez wieśniaków, przypisując sobie w zamian prawo pobierania z tego tytułu danin i robocizn. W tym ujęciu zyskiwały one charakter świadczeń niejako publiczno-prawnych, o ile można mówić o tego rodzaju rozróżnieniach w warunkach państwa patrymonialnego. Początkowo władca ściągał je we własnym imieniu przy pomocy aparatu państwowego (administracji grodowej), z czasem (od połowy XI w.) prawo to zacząl nadawać indywidualnym odbiorcom: możnym, instytucjom kościelnym, rycerstwu (o czym wspomniano wyżej). To właśnie prawo poboru świadczeń książęcych, a nie ziemia i ludzie, stawało się przedmiotem najwcześniejszych nadań. Władcy dokonywali ich ustnie, zgodnie z ówczesnymi zwyczajami prawnymi. Dopiero w XIII w. nadania takie zaczęto utrwalać na piśmie, a w warunkach znacznie posuniętej już feudalizacji opisywano je w stosownych dokumentach jako nadanie własności ziemi i ludzi. Dlatego też duża część historiografii widziała monarchę jako poprzedniego właściciela gruntów uprawianych przez wieśniaków i nadanych później posiadaczom prywatnym. G. Labuda opowiedział się za stanowiskiem, że taka interpretacja monarszego prawa pobierania świadczeń pojawiła się dopiero w XIII w., w dobie postępującej feudalizacji społeczeństwa i w tej formie znalazła wyraz w wydawanych wówczas aktach prawnych ${ }^{9}$. Ogólnie uczony podkreślał bezpośredni związek zachodzących przemian społecznych z wy-

7 H. Łowmiański, Początki Polski, t. 3, Warszawa 1967, s. 107-108 n.

8 K. Modzelewski, Organizacja gospodarcza państwa piastowskiego X-XIII w., Wrocław 1975; tenże, Chłopi w monarchii wczesnopiastowskiej, Wrocław 1987.

9 G. Labuda, Korona i infuła, s. 28-30. Autor wskazuje tu konkretnie przykłady poglądów H. Łowmiańskiego i K. Modzelewskiego, przytaczając stosowne fragmenty ich publikacji. 
tworzeniem się organizacji państwowej. To struktury państwowe i tworzona przez nie nowa rzeczywistość generowały oraz przyspieszały te przemiany. Rodzące się państwo piastowskie nie dokonywało jednak zmian o charakterze rewolucyjnym, niszczących całkowicie dotychczasowe stosunki. Przeciwnie, zdaniem G. Labudy starało się wykorzystać i przystosować do swoich potrzeb elementy dotychczasowej struktury społecznej i organizacji opolnej. Monarchia nie miała po prostu innej możliwości i musiała w dużym stopniu opierać się na tych urządzeniach, co prawda wywierając zarazem przemożny wpływ na ewolucję tychże struktur ${ }^{10}$.

A. Gieysztor nie podejmował już w późniejszych latach swojej pracy naukowej prób tworzenia syntezy obejmującej polityczne, społeczne czy gospodarcze dzieje monarchii piastowskiej. W tematyce tej odnosił się natomiast niejednokrotnie do kwestii bardziej szczegółowych, badając konkretne przejawy funkcjonowania struktur państwa polskiego. Jeden z klasycznych tematów podejmowanych przez historiografię stanowiły tutaj wysiłki zmierzające do określenia pochodzenia oraz istoty poszczególnych danin i służebności pobieranych od mieszkańców w ramach świadczeń tzw. „prawa książęcego”. W nurt tego rodzaju badań A. Gieysztor włączył się artykułem poświęconym daninom łowieckim w prawie książęcym ${ }^{11}$. Ta gruntowna, oparta na znajomości źródeł rozprawa ukazuje warsztat badawczy Autora oraz stanowi wyraz ogólniejszego przekonania o możliwości wykorzystywania metody retrogresji. Stosunkowo nieliczne wzmianki o daninach łowieckich pochodzące z dokumentów trzynastowiecznych (częściowo zresztą podejrzanych co do ich autentyczności) zostały wsparte liczniejszymi informacjami źródłowymi z wieków XIV i XV, co pozwoliło na sformułowanie szerszych wniosków dotyczących pochodzenia, funkcjonowania oraz zaniku tego rodzaju świadczeń w dawnej Polsce.

Zagadnieniem, które przyciągnęło uwagę obydwu uczonych i w którym wypowiadali się wielokrotnie w bardzo zbliżonym tonie, stała się kwestia początków miast i życia miejskiego w średniowiecznej Polsce i ogólniej w całej Europie Środkowej. Problem ten wywoływał liczne kontrowersje w literaturze przedmiotu oraz stanowił przez długi czas jeden z głównych punktów spornych pomiędzy historiografią niemiecką a historiografią państw środkowoeuropejskich, w szczególności polską. Najważniejsza kontrowersja dotyczyła znaczenia aktu lokacji dla powstania miasta oraz rodzimych bądź kolonialnych korzeni życia miejskiego w tej części Europy.

10 Tamże, s. 20-49.

11 A. Gieysztor, Owies $w$ daninach łowieckich $w$ Polsce średniowiecznej, Kwartalnik Historii Kultury Materialnej 9 (1963), z. 2, s. 213-234. 
Historiografia niemiecka stała konsekwentnie na stanowisku, że to akt lokacji na „nowym prawie” (czyli tzw. prawie niemieckim) tworzył osadę miejską we właściwym tego słowa znaczeniu, tzn. jako wspólnotę mieszkańców (komunę), obdarzoną szczególnymi przywilejami wyróżniającymi osadę wśród innych, okolicznych osiedli ludzkich. W tym ujęciu początki miast środkowoeuropejskich miały mieć charakter „kolonialny”, osady tego rodzaju powstawały wraz z napływem od XII/XIII w. niemieckich kolonistów, przynoszących własne, wypracowane na Zachodzie i nieznane w Europie Środkowej formy prawno-organizacyjne. Historiografia polska odrzucała zasadniczo ten pogląd, przypisując większą rolę miastotwórczą czynnikom ekonomicznym i postulując rozumienie terminu „miasto” przede wszystkim jako osady będącej ośrodkiem działalności rzemieślniczo-handlowej. W takim z kolei ujęciu miasta środkowoeuropejkkie miały formować się dużo wcześniej na rodzimych podstawach (zdaniem niektórych badaczy nawet już w dobie przedpaństwowej), a grody i otaczające je podgrodzia uważano za ośrodki wczesnomiejskie. Późniejsza lokacja na prawie niemieckim miała stanowić tylko nadanie nowej, ulepszonej formy organizacyjnej. Była więc tylko reformą, służącą dalszemu rozwojowi danego ośrodka.

Dyskusja przybierała często formę burzliwą i niewolną od elementów propagandowych oraz ideologicznych, powiązanych z bieżącą sytuacją polityczną ${ }^{12}$. Zarówno A. Gieysztor, jak i G. Labuda opowiedzieli się zdecydowanie za rodzimymi, miejscowymi korzeniami życia miejskiego na ziemiach polskich, czemu dali wyraz w licznych publikacjach oraz wystąpieniach na arenie krajowej i międzynarodowej. Nie ograniczali się przy tym do podkreślania ekonomicznej roli ośrodków wczesnomiejskich (podgrodzi, osad targowych) jako centrów produkcji rzemieślniczej i handlu, lecz starali się zanegować również podstawową tezę historiografii niemieckiej o braku specyficznych, „miejskich” form prawno-ustrojowych na ziemiach środkowoeuropejskich przed epoką „kolonizacji na prawie niemieckim”. Obydwaj badacze podjęli wysiłek wykazania, że takie rozwiązania prawne istniały i można mówić o funkcjonowaniu czegoś w rodzaju „polskiego prawa miejskiego”, poprzedzającego późniejsze prawo niemieckie wprowadzane w aktach lokacji. Przyznawali przy tym, że rodzime prawo miejskie ustępowało pod wieloma względami napływowemu „prawu niemieckiemu” i dlatego zostało ostatecznie wyparte. Sam fakt jego funkcjonowania miał jednak dowodzić, że „miasta przedlokacyjne” były ośrodkami o charakterze miejskim także w ściśle prawnym, zachodnioeuropejskim znaczeniu.

12 Przegląd poglądów starszej literatury zob: H. Łowmiański, Początki Polski, t. 6, cz. 2, Warszawa 1985, s. 649-668. 
To z kolei pozwalało odrzucać poglądy historiografii niemieckiej o kolonialnych początkach życia miejskiego na wschodzie Europy oraz pojawiające się opinie o ogólnej niższości cywilizacyjnej Słowian i innych ludów Europy Środkowo-Wschodniej, dla których wspomniana kwestia początków osad miejskich stanowiła jeden z ważniejszych argumentów.

Owym poszukiwanym i postulowanym przez obydwu Autorów polskim odpowiednikiem zachodnioeuropejskiego prawa miejskiego miało być prawo targowe (ius forense). Istotnie, instytucja targu oraz prawo jego urządzania odgrywały kluczową rolę zarówno w akcie lokacji, jak i dla późniejszego funkcjonowania miasta, a targi i osady targowe funkcjonowały w Polsce od czasów pierwszych Piastów, podlegając specjalnym regulacjom prawa książęcego. Prawo ustanawiania targu stanowiło monopol monarszy, element systemu regaliów, a w trakcie odbywania samego targu obowiązywały specyficzne zwyczaje prawne. Zdaniem A. Gieysztora, najpóźniej w XII w. wykształcić się miały na tej podstawie elementy odrębnej, stałej organizacji sądowej i administracyjnej, stanowiącej o specyfice ustrojowej ośrodków wczesnomiejskich (podgrodzi). Szczególną rolę przypisywał tutaj wzmiankowanemu niekiedy w źródłach urzędowi sędziego targowego (iudex forense) - w czym szedł zresztą za dawniejszymi uwagami R. Grodeckiego ${ }^{13}$. Bardzo podobne stanowisko zajął w tej dyskusyjnej kwestii G. Labuda, idąc nawet dalej niż A. Gieysztor. Sformułował on wprost tezę o istnieniu „polskiego prawa miejskiego”, mającego stanowić na naszych ziemiach odpowiednik późniejszego „prawa niemieckiego” i obejmującego swymi regulacjami całość problemów związanych z funkcjonowaniem ośrodków miejskich poprzedzających epokę lokacji. W takim ujęciu, pod względem formalnym, ośrodki te w niczym nie ustępowałyby późniejszym miastom lokacyjnym ${ }^{14}$. Tezy te, odbijające się dużym echem i żywo dyskutowane w latach pięćdziesiątych oraz sześćdziesiątych XX w., zostały jednak następnie poddane krytyce i w znacznym stopniu zanegowane przez K. Buczka. Autor ten uznał, że tworzenie historiograficznej konstrukcji „polskiego prawa miejskiego”, mającego stanowić odpowiednik

13 A. Gieysztor, Les origines de la ville slave, [w: L La cittă nell' alto medioevo, Settimane di studio del Centro Italianodi studi sull' alto med. 6, Spoleto 1959, s. 279-303; tenże, Le origini della cittè nella Polonia medievale, [w:] Studi in onore di Armando Sapori, Milano 1957, s. 129-145; R. Grodecki, Targi $w$ Polsce $w$ dobie przed kolonizacja miast na prawie niemieckim, Studia Akademii Umiejętności 27 (1922), nr 4, s. 13-14.

14 G. Labuda, Miasta na prawie polskim, [w:] Studia historica w 35-lecie pracy naukowej Henryka Łowmiańskiego, Warszawa 1958, s. 181-197; tenże, Villes de „droit polonais”, [w:] Les origines des villes polonaises, Paris 1960, s. 53-71. 
niemieckiego prawa lokacyjnego we wszystkich jego aspektach, jest pozbawione poważniejszych podstaw źródłowych i do kwestii tych podchodzić należy z dużą powściągliwością ${ }^{15}$. Współczesna historiografia stara się zazwyczaj wcielać w życie ten ostatni postulat.

Podsumowując powyższe rozważania na temat miejsca zagadnień związanych z organizacją państwa i społeczeństwa polskiego doby piastowskiej w problematyce badawczej A. Gieysztora i G. Labudy, dostrzec można pewne wspólne rysy w podejściu obydwu uczonych. Obydwaj przywiązywali dużą wagę do wspomnianych kwestii, co nie było zresztą niczym niezwykłym zarówno dla ówczesnej generacji historyków, jak i dla pokolenia ich mistrzów. Kontynuowali więc dłuższą tradycję historiografii polskiej. Zarówno dla A. Gieysztora, jak i G. Labudy zagadnienia dziejów ustroju państwa i stosunków społecznych stanowiły wprawdzie tylko część zainteresowań badawczych, do tematu tego regularnie jednak powracali, w szczególności G. Labuda. Obydwaj uczeni podzielali przy tym przekonanie, że kwestie te mogą być $\mathrm{z}$ powodzeniem badane i poznawane pomimo bardzo skromnej podstawy źródłowej, w szczególności małego zasobu źródeł pisanych. Doceniali znaczenie badań archeologicznych, poszerzających dostępną podstawę źródłową, przede wszystkim uważali jednak, że historykowi państwa i społeczeństwa doby wczesnopiastowskiej mogą służyć pomocą metody porównawcze oraz retrogresja. Odwoływali się do porównań z warunkami panującymi w państwach ościennych oraz wnioskowali na podstawie wiadomości zawartych w późniejszych źródłach pochodzenia rodzimego. Przekonaniu temu dawali wyraz przede wszystkim we własnej praktyce badawczej i ogłaszanych publikacjach. Podejmowali przy tym tematy ważne nie tylko z powodów czysto naukowych, lecz także takie, które wiązały się z bieżącymi polemikami o zabarwieniu propagandowym. W szczególności chodziło tu o trwającą wówczas od kilkudziesięciu lat dyskusję z historiografią niemiecką na temat korzeni życia miejskiego w Polsce i całej Europie Środkowej. Poglądy obydwu uczonych, przedstawione dobitnie na przełomie lat pięćdziesiątych i sześćdziesiątych XX w., stanowiły najbardziej rozbudowaną w historiografii polskiej próbę obrony tezy o całkowicie rodzimych, niezależnych od wpływów niemieckich początkach ośrodków miejskich w tej części Europy. Te ostatnie hipotezy literatura przedmiotu uznała później za zbyt daleko idące i sformułowane nieco na wyrost. Wiele innych tez, np. poglądy G. Labudy o decydującej roli monarchii i jej aparatu dla postępującego procesu rozwarstwienia i feudalizacji społeczeństwa czy też o zmilitaryzowanym charakterze

15 K. Buczek, Targi i miasta na prawie polskim, Wrocław 1964. 
państwa pierwszych Piastów, weszło natomiast na trwałe do dorobku mediewistyki polskiej. Trzeba w tym miejscu zaznaczyć, że problematyką ustroju państwa oraz organizacji społeczeństwa A. Gieysztor zajmował się szerzej we wcześniejszych latach swojej pracy naukowej, które przypadły zasadniczo na okres bezpośrednio powojenny, zdominowany w naukach humanistycznych narzucanymi odgórnie ideologią i metodologią marksistowską, ujmowanymi zresztą często w formie zwulgaryzowanej. Znalazło to pewne obicie w ówczesnych publikacjach uczonego. W kolejnych dekadach uwagę A. Gieysztora przyciągaty raczej inne zagadnienia i do wspomnianej problematyki powracał stosunkowo rzadko. Inaczej G. Labuda, dla którego kwestie społeczne i ustrojowe zawsze stanowiły znaczącą część tematyki pracy badawczej. Dzięki temu mógł się ustosunkować do późniejszych osiągnięć zwłaszcza archeologii, której odkrycia rzuciły nowe światło na kwestie związane z początkami państwowości piastowskiej. Dał temu wyraz w pracach o charakterze syntetycznym i formalnie popularnonaukowym, opublikowanych w dwóch ostatnich dekadach życia. Znaczenia osiągnięć obydwu historyków dla postępu badań nad organizacją państwa i społeczeństwa piastowskiego nie sposób przecenić.

Nadesłany: 10 IX 2020

Nadesłany po poprawkach recenzyjnych: 10 VI 2021

Zaakceptowany: 10 VI 2021

Prof. dr hab. Zbyszko Górczak

Wydzial Historii, Uniwersytet im. Adama Mickiewicza w Poznaniu

ul. Uniwersytetu Poznańskiego 7

61-614 Poznań

e-mail: zbyszkog@amu.edu.pl

\section{Résumé}

\section{Organisation of the Polish State and Society in the Piast Era} in the Academic Work of Aleksander Gieysztor and Gerard Labuda

A. Gieysztor dealt with the issue of the origins and organisation of the Polish state and the then social transformations mainly earlier in his life, formulating opinions which were in line with the postulates of Marxist methodology. For example, he claimed that the formation of a state organisation was the result of a prior feudalisation of society, which had already begun in the tribal era. G. Labuda made the above topic a key one in his entire scholarly career, with time indicating the decisive role of the state in stimulating social change. He also 
stressed the importance of the militarisation of the state of the first Piasts. In the 1950s, both scholars became involved in promoting the thesis of the native, pre-colonisation origins of urban life in the Polish lands, negating internationally the claims of German historiography, which ascribed a decisive role to newcomers from Germany and the reception of German political models. A. Gieysztor and G. Labuda sought to substantiate the role of the market law (ius forense) as a native counterpart and predecessor of the German municipal law, views that were later challenged. It should also be emphasised that both scholars recognised the retrogression and comparative methods as key procedures for the studies of early Piast Poland, and that G. Labuda made use of all recent archaeological findings.

Translated by Agnieszka Tokarczuk

\section{Bibliografia/Bibliography}

Buczek K., Targi i miasta na prawie polskim, Ossolineum 1964

Gieysztor A., Le origini della cittè nella Polonia medievale, [w: ] Studi in onore di Armando Sapori, Milano 1957, s. 127-145

Gieysztor A., Les origines de la ville slave, [w: ] La cittè nell' alto medioevo - Settimane di studio del Centro Italianodi studi sull' alto med. 6, Spoleto 1959, s. 279-303

Gieysztor A., Owies $w$ daninach łowieckich $w$ Polsce średniowiecznej, Kwartalnik Historii Kultury Materialnej 9 (1963), z. 2, s. 213-234

Grodecki R., Targi w Polsce $w$ dobie przed kolonizacja miast na prawie niemieckim, Studia Akademii Umiejętności 27 (1922), nr 4, s. 3-27

Historia Polski, t. I, cz. 1, red. H. Łowmiański, Warszawa 1957

Labuda G., Korona i infuta. Od monarchii do poliarchii, Warszawa 1996

Labuda G., Miasta na prawie polskim, [w:] Studia historica w 35-lecie pracy naukowej Henryka Łowmiańskiego, Warszawa 1958, s. 181-197

Labuda G., Mieszko I, Ossolineum 2002

Labuda G., Pierwsze państwo polskie, Warszawa 1989

Labuda G., Przeobrażenia w organizacji polskich sił zbrojnych w XI w., [w:] Pax et bellum, red. K. Olejnik, Poznań 1993, s. ?

Labuda G., Villes de „droit polonais”, [w:] Les origines des villes polonaises, Paris 1960, s. 53-71

Łowmiański H., Początki Polski, t. 6: Polityczne i społeczne procesy ksztattowania się narodu do początku wieku XIV, cz. 2, Warszawa 1985

Łowmiański H., Początki Polski. z dziejów Stowian w I tysiącleciu n. e., t. 3, Warszawa 1967 
Modzelewski K., Chtopi w monarchii wczesnopiastowskiej, Wrocław 1987

Modzelewski K., Organizacja gospodarcza państwa piastowskiego X-XIII w., Wrocław 1975 